\title{
Poor practices of medical and health sciences students for the prevention of hepatitis B viral infections in Ethiopia
}

\author{
Genene Fiseha ${ }^{1}$, Belay Tafa ${ }^{2}$ \\ 'School of Medicine, College of Medicine and Health Sciences, \\ Dire Dawa University, Dire Dawa, Ethiopia \\ ${ }^{2}$ Department of Medical Laboratory Sciences, \\ College of Medicine and Health Sciences, Ambo University, Ambo, Ethiopia
}

doi: 10.3396/IJIC.v15i1.003.19

\begin{abstract}
Hepatitis B virus (HBV) is a serious global public health problem and health professionals, especially medical and health sciences students, are at risk of acquiring infection through occupational exposure. Hence, this study was aimed at assessing medical and health sciences students' knowledge, attitudes and practices towards HBV transmission and prevention.
\end{abstract}

A cross-sectional study was conducted from February to March, 2017 among 190 medical and health sciences students. Study participants were selected using random sampling technique. A self-administered questionnaire was used to collect information. Data were analyzed using SPSS version 20.

Out of 190 distributed questionnaires, all were returned with a response rate of $100 \%$. Majority of the students, 107 (56.3\%), were in the age group 20 - 24 years. Almost all the respondents had good knowledge about HBV transmission, treatment and prevention. The majority $(179,94.2 \%)$, of students had good attitudes towards the importance of standard precautions, vaccine and post exposure prophylaxis for HBV prevention. However, the study participants had poor practices towards the prevention of hepatitis B infections where $164(86.3 \%)$ of the students had not been vaccinated against and screened for the virus and $111(58.4 \%)$ of them were not practicing of the standard precautions.

This study indicates that participants had good knowledge and attitudes towards HBV prevention. However, they had experienced poor practice while giving healthcare services.

Keywords: prevention, hepatitis B virus, knowledge, attitudes, medical students, Ethiopia

\author{
Corresponding Author \\ Belay Tafa \\ Postal Address: P.O.Box 19; Ambo, Ethiopia \\ E-mail address: belaytf@gmail.com
}




\section{Introduction}

In general, there are six common known types of hepatitis viruses, namely hepatitis A, B, C, D, E and $\mathrm{G}$; all cause hepatitis, the inflammation of the liver. Amongst all, hepatitis $B$ and $C$ viruses are the common causes of chronic liver disease and permanent liver damage. Hepatitis A, E and G are typically transmitted primarily through ingestion of contaminated food and water while hepatitis $B, C$, and D are primarily transmitted via the mucocutaneous route, unprotected sex, infected blood transfusion, and use of nonsterilized needles and syringes (injection drug use, tattooing, scarification and nosocomial transmission). ${ }^{1}$ Hepatitis B virus (HBV) causes serious public health problems worldwide affecting the liver. According to the geographic areas, the global prevalence of chronic HBV infection can be classified into high, intermediate and low endemicity areas. Forty five percent of the world population lives in highly endemic areas, $43 \%$ live in areas of intermediate endemicity and $12 \%$ live in areas of low endemicity. ${ }^{2}$ As in the 2009 WHO report, about 2 billon people are affected with HBV worldwide, more than 350 million suffer from chronic lifelong infection with chronic HBV and more than one million of individuals die because of chronic hepatitis, cirrhosis and hepatocellular carcinoma. Among the chronically infected, 65 million of them reside in Africa. Thus, Africa carries $15-18 \%$ of the global burden of HBV infection. The prevalence of HBV in Africa was estimated to be $8 \%$ in West Africa, 5 - 7\% in Central, Eastern, and Southern Africa ${ }^{3}$ showing that the burden of viral hepatitis was significantly high in Africa as compared to developed countries.

The occupational risk for HBV acquisition varies according to the workplace in the healthcare setting and time of exposure to the agent such as blood, serum and wound exudates which have high risk; semen, vaginal fluid and saliva have moderate risk and urine, feces, sweat, tears and breast milk have low risk. ${ }^{4}$

TheWHO estimated that out of the 35 million healthcare workers (HCWs) worldwide, three million experience percutaneous exposures to blood pathogens each year, of these two million are exposed to HBV, 0.9 million to hepatitis C virus (HCV) and 170,000 to human immunodeficiency virus (HIV). ${ }^{5}$ Different studies conducted among HCWs showed that they are at risk of acquiring blood borne disease including HBV, HCV and HIV compared to any other occupational group due to occupational exposure. In line with this, a study done among HCWs and non HCWs in Southern Oromia, Ethiopia, showed HBV was detected in 7.3\% of HCWs and $0.9 \%$ of non HCWs. ${ }^{6}$ A study conducted among HCWs and medical students in University of Gondar Hospital revealed that the overall lifetime and one year prevalence of occupational exposure to blood and body fluids (BBFs) were $70.2 \%$ and $62.9 \%$, respectively. The exposure rate of BBFs was highest among interns, 90.6\%, followed by HCWs, $63.3 \%$ and lowest among housekeeping staff, $45.2 \%{ }^{7}$ this shows that students are also at high risk for infection and transmission of HBV to other individuals.

Different research showed that probably the disease has a long history in our country. Studies in Jimma University Hospital, ${ }^{8}$ Amhara and Tigray regional states, ${ }^{9}$ Bahir Dar Felege Hiwot Referral Hospital ${ }^{1}$ and Dire Dawa City $^{10}$ among blood donors showed that the prevalence rate of hepatitis B surface antigen ( $\mathrm{HBsAg}$ ) among students was $12.5 \%, 13.5 \%, 3.1 \%, 20 \%$ and $3.4 \%$, respectively. Despite the long history of the disease in the country, there have not been any bold and pragmatic measures put in place to curb it except the introduction of hepatitis $B$ vaccine into national immunization schedules by March 2007, particularly for newly born infants, aged 6-14 weeks. ${ }^{11}$

Studies conducted in United Arab Emirates and Côte$\mathrm{d}^{\prime}$ Ivoire showed books, media, school and HCWs as the most important information sources for the university students for prevention of infection of HBV. ${ }^{12}$ On the other hand, in Ethiopia, media publicity on this disease is not substantial as compared to other infectious diseases. Therefore, health sciences students and even HCWs do not have any source to obtain information out of school curricula about this deadly disease. In Ethiopia, medical and health sciences students practice in all clinical settings where healthcare services are delivered. Hence, medical and health sciences students, being part of the healthcare delivery system, are exposed to the same risk as HCWs while coming in contact with patients and contaminated instruments. As one study revealed, because of lack of awareness about the disease transmission, most medical students do not practice universal precautions on a routine basis. ${ }^{13}$ 
A press report published on March, 28, 2013 claimed that over 10 million Ethiopians are infected with HBV and the majority of the infected population is unaware of their disease status. ${ }^{14}$ In Ethiopia, the limited knowledge on hepatitis prevalence as well as the minimal awareness about the disease can increase the risk of infections and transmission from patients to medical and health sciences students or healthcare workers and vice versa during healthcare delivery to the patients. Therefore, this study was aimed at assessing medical and health sciences students' knowledge, attitudes and practices towards HBV transmission and prevention in Dire Dawa University.

\section{Materials and Methods}

\section{Study Design, Period and Setting}

A cross-sectional study was conducted at College of Medicine and Health Sciences of Dire Dawa University from February to March 2017. Dire Dawa University is one of the public educational institutions found in 2006/07 academic year. However, the School of Medicine was begun with the birth of the New Innovative Medical Education Initiative (NIMEI) in 2011 having an objective of alleviating the scarcity of physicians in Ethiopia. Besides the medical program, anesthesia and midwifery departments were opened in the 2013/2014 academic year, and the college was named as College of Medicine and Health Sciences in 2015/16.

\section{Source and study population}

The source population for the study was all medical and health science students of Dire Dawa University. The study populations for this study were selected $3^{\text {rd }}$, $4^{\text {th }}, 5^{\text {th }}$ and $6^{\text {th }}$ year medical students as well as $2^{\text {nd }}$, $3^{\text {rd }}$ and $4^{\text {th }}$ year midwifery and anesthesia students of the University. Medical and health sciences students attending second year and above who had taken infectious diseases related courses and started clinical attachment were included in the study. Students not yet started a clinical attachment, those having mental illness or serious illness as well as those who have not taken infectious diseases related courses were excluded from the study.

\section{Sample Size Estimation}

The sample size was determined using a single population proportion formula. A prevalence rate of $50 \%$ knowledgeable students, $5 \%$ margin of error and a $95 \%$ confidence interval of certainty $(=0.05)$ were used to calculate the sample size. Based on these assumptions, sample size was computed as follows.

\section{Sampling Technique}

Study participants were selected using a systematic sampling technique. First, we stratified students based on year of study and department. Next, the sample size was distributed proportionally to each year of study based on the student population. Finally, using

$$
\begin{array}{ll}
n=\frac{\left(Z_{\frac{\alpha}{2}}\right)^{2} P(\mathbf{1}-P)}{d^{2}} & \text { Where } \mathrm{n}=\text { sample size of population for } \mathrm{N}>10,000 \\
n=\frac{(\mathbf{1 . 9 6})^{2}(\mathbf{0 . 5})(\mathbf{0 . 5})}{(\mathbf{0 . 0 5})^{2}} & \mathrm{P}=\text { assumed percentage of knowledgeable students } \\
\boldsymbol{n}=\mathbf{3 8 4} & \mathrm{d}=\text { marginal of error } 5 \%(0.05) \\
& \mathrm{Z}_{\alpha / 2}=\text { the reliability coefficient of } 95 \% \text { i.e. } 1.96
\end{array}
$$

The calculated sample size was $\mathbf{3 8 4}$. Since the source population was $\mathbf{3 7 3}$ (which is less than 10,000), we used a correction formula ${ }^{15}$ to determine the corrected sample size, $\mathrm{n}_{\mathrm{o}}$.

$$
\begin{aligned}
& \mathrm{n}_{\mathrm{o}}=\frac{\mathrm{n}}{1+\frac{\mathrm{n}}{\mathrm{N}}}=\frac{384}{1+\frac{334}{373}}=\sim 190 \quad \text { Where } \mathrm{n}_{\mathrm{o}}=\text { the sample size for a population }<10000 \\
& \mathrm{n}=\text { the sample size for a population had it been }>10000 \\
& \mathrm{~N}=\text { the size of the entire population }
\end{aligned}
$$

The final sample size for this study was $\mathbf{1 9 0 .}$ 
Table I. Proportional allocation of the sample size of students at College of Medicine and Health Sciences, Dire Dawa University

Department

\author{
Year of study
}

Number of
Students $\left(\mathbf{n}_{0}\right)$
Sampling fraction, Proportional size

$\frac{n}{N}=\frac{190}{373}=0.51$

$n_{1}=0.51 \times n_{o}$

\begin{tabular}{|c|c|c|c|c|c|}
\hline \multirow[t]{4}{*}{1} & Medicine & $3^{\text {rd }}$ & 37 & $0.51 \times 37$ & 19 \\
\hline & & $4^{\text {th }}$ & 46 & $0.51 \times 46$ & 24 \\
\hline & & $5^{\text {th }}$ & 40 & $0.51 \times 40$ & 20 \\
\hline & & $6^{\text {th }}$ & 44 & $0.51 \times 44$ & 22 \\
\hline \multirow[t]{3}{*}{2} & Anesthesia & $2^{\text {nd }}$ & 18 & $0.51 \times 18$ & 9 \\
\hline & & $3^{\text {rd }}$ & 23 & $0.51 \times 23$ & 12 \\
\hline & & $4^{\text {th }}$ & 29 & $0.51 \times 29$ & 15 \\
\hline \multirow[t]{4}{*}{3} & Midwifery & $2^{\text {nd }}$ & 40 & $0.51 \times 40$ & 20 \\
\hline & & $3^{\text {rd }}$ & 54 & $0.51 \times 54$ & 28 \\
\hline & & $4^{\text {th }}$ & 42 & $0.51 \times 42$ & 21 \\
\hline & Total & & 373 & & 190 \\
\hline
\end{tabular}

student lists, respondents were selected independently from each stratum by systematic random sampling. In case of absenteeism the next student was included in the study (Table I).

\section{Data Collection}

Data were collected using structured and selfadministered closed-ended questions. Thequestionnaire was prepared in English language consisting of four sections. The first section contained socio-demographic characteristics of the respondent. The second section was designed to assess the knowledge about mode of transmission, sequelae and prevention of HBV. The third and fourth sections contained questions related to participants' perception toward the risk of acquiring HBV infection and practice of precautions to prevent themselves from contracting the disease.

\section{Data Quality Control}

To ascertain completeness and clarification before implementing data collection, the questionnaire was pretested on $5 \%$ of medical and health sciences students of Haramaya University and Jijiga University who were on clinical attachment at Dil Chora Hospital, and the necessary modifications were made.

\section{Operational Definition}

Assessment: the process of measuring the level of knowledge, attitudes and practices of medical and health sciences students regarding HBV infections using a structured, self-administered questionnaire.

Knowledge: 18 major questions were prepared to each participant to assess knowledge about route of transmission, sign, symptoms, sequelae, and prevention of HBV infection. Each response was scored as 'yes' or 'no'. Each correct answer was given a score of ' 1 ' while a wrong answer was given a score of ' 0 '. Students' knowledge was classified into two levels according to the total score obtained; a total score of $\leq 8$ (correctly answered $<50 \%$ ) was regarded as having poor knowledge, and 9 or more (correctly answered $\geq 50 \%$ ) was considered as having good knowledge.

Attitude: Seven major questions were prepared to assess attitudes of participants toward HBV infection. Each response scored as 'yes' or 'no'. The scoring range of the questionnaire was 7 (largest) to 0 (smallest). Those who have answered yes to more than $50 \%(\geq 4)$ of questions were considered as having good attitudes toward HBV infection and prevention, 
whereas below $50 \%$ percent ( $<4$ questions) was considered as having bad attitudes.

Practice: four major questions were prepared to assess practice of participants toward the prevention of HBV infection. Each response was scored as 'yes' or 'no'. Each correct answer was given a score of ' 1 ' while a wrong answer was given a score of ' 0 '. Each question was labelled as good or poor practice.

\section{Variables in the study}

Knowledge, attitude, and practice of the study participants towards HBV transmission and prevention were considered as dependent variables; and sex, age, residence areas, marital status, religion, year of study and departments of the study population were considered as the independent variables. Risk factors for HBV infection such as history of blood transfusion, history of medical and surgical procedures, exposure to blood or other body fluids, needle sticks and sharp objects exposure and source of information on HBV were also considered as independent variables.

\section{Data Entry and Analysis}

Data were checked for completeness and consistency. Coded data were entered and cleaned using Epi Data software (The EpiData Association, Odense, Denmark) and analyzed using SPSS version 20.0 (IBM, Armonk NY). Descriptive statistics such as frequencies and proportions were used to summarize the data. Bivariate and multivariate analyses were carried out using logistic regression to examine the relationship between the outcome variables and selected sociodemographic factors. Adjusted and unadjusted odds ratios $(\mathrm{OR})$ and their $95 \%$ confidence intervals $(\mathrm{Cls})$ were used as indicators of the strength of association. A p-value of less than 0.05 was considered statistically significant.

\section{Results}

\section{Socio-Demographic Characteristics of the Study Participants}

A total of 190 students were included from three different departments in the study with a response rate of $100 \%$. The majority of the students, $107(56.3 \%)$, was within the age group of 20-24, and 145 (76.3\%) of the respondents were males. Of the study participants, $171(90 \%)$, were single in marital status, and 124 $(65.3 \%)$ came from urban area (Table II).

\section{Knowledge of HBV}

Regarding knowledge questions, all the respondents, 190 (100\%), had good knowledge about hepatitis B route of transmission, its sign and symptoms, sequelae, treatment and prevention of the infection. Regarding the route of transmission, all the respondents knew that HBV can be contracted from contaminated blood and blood products. They also responded that the transmission of HBV would be through unsafe sex, 179 (94.2\%), mother to child, 172 (90.5\%), unsterilized syringes, needles and surgical instruments, $167(87.9 \%)$ and sharing toothbrush with an infected person, $159(83.7 \%)$. A majority of the students were right that $\mathrm{HBV}$ is not transmitted through sharing of food with an infected person, 145 (76.3\%), through the air, $184(96.8 \%)$ and by holding hands of infected person, $114(60 \%)$.

Of 190 respondents, 173 (91.1\%) were correctly responded that HBV is not hereditary, and $174(91.6 \%)$ of them recognized that HBV is more easily transmitted than HIV. Concerning signs and symptoms of HBV disease, all the respondents gave correct answers.

Regarding the sequelae of HBV infection, 167 (87.9\%) mentioned that HBV can cause liver cancer and 111 (58.4\%) considered that HBV affects other organs like kidney, skin, brain etc. In terms of knowledge about preventive measures, 186 (97.9\%) of the participants responded that it is possible to prevent hepatitis B transmission, and $144(75.8 \%)$ considered that it a treatable disease while $169(88.9 \%)$ of respondents correctly identified as vaccination is a way of preventing HBV infection. 139 (73.2\%) of the study participants knew that HBV has post exposure prophylaxis.

As the most important source of information about $\mathrm{HBV}$, the participants mentioned class room lecture $(129,67.9 \%)$, television $(8,4.2 \%)$, radio $(5,2.6 \%)$, training or seminar $(26,13.7 \%)$, and different reading materials like news paper, pamphlet and brochures $(22,11.6 \%)$. The mean knowledge score for the entire study was $15.12 \pm 1.97$ (Table III).

\section{Attitudes toward $\mathrm{HBV}$ infection and prevention}

Of the 190 participants, only 11 (5.8\%) had bad attitudes towards HBV infection and prevention. Concerning their jobs, the majority of the participants (181, 95.3\%), believed that their jobs increased the risk of HBV 
Table II. Socio-demographic characteristics of the study participants

\section{Characteristics}

Numbers

Percent $(\%)$

\section{Sex}

Male

145

76.3

Female

45

23.7

Age

\begin{tabular}{lcc}
\hline $15-19$ & 1 & 0.5 \\
\hline $20-24$ & 107 & 56.3 \\
\hline $25-29$ & 49 & 25.8 \\
\hline $30-34$ & 28 & 14.7 \\
\hline$\geq 35$ & 5 & 2.6
\end{tabular}

Department

\begin{tabular}{lll}
\hline Medicine & 85 & 44.7 \\
\hline Midwifery & 69 & 36.3 \\
\hline Anesthesia & 36 & 18.9 \\
Year of study & & \\
\hline
\end{tabular}

\begin{tabular}{llc}
\hline Second year & 29 & 15.3 \\
\hline Third year & 59 & 31 \\
\hline Fourth year & 60 & 31.5 \\
\hline Fifth year & 20 & 10.5 \\
\hline Sixth year & 22 & 11.6
\end{tabular}

Marital status

\begin{tabular}{lcc}
\hline Single & 171 & 90 \\
\hline Married & 19 & 10 \\
Religion & & \\
\hline
\end{tabular}

\begin{tabular}{lcc}
\hline Orthodox & 95 & 50 \\
\hline Muslims & 63 & 33.2 \\
\hline Protestant & 26 & 13.7 \\
\hline $\begin{array}{l}\text { Other } \\
\text { Residence }\end{array}$ & 6 & 3.2 \\
\hline Urban & & 65.3 \\
\hline Rural & 124 & 34.7
\end{tabular}

infection. Regarding hepatitis B vaccine, 125 (65.8\%) of respondents had misconception about hepatitis B vaccine requirement for complete protection. Out of 190 respondents, 110 (57.9\%) believed that all patients should be tested for HBV before receiving health care. Concerning care giving to HBV infected patients, 109 (57.4\%) of respondents did not give the same standard of care for patients with HBV as they did for others. $183(96.3 \%)$ of respondents believed that education is effective in improving knowledge on hepatitis $B$. The data revealed that all the study participants had good attitudes towards standard precautions important to control hospital acquired infections. The mean score related to attitude was $5.05 \pm 0.99$ (Table IV). 
Table III. Responses of the study participants to HBV knowledge item questions

Hepatitis B Virus Knowledge Items

Responses

\begin{tabular}{llcc}
\hline & & Yes & No \\
\hline & $\begin{array}{l}\text { Knowledge about } \\
\text { infection }\end{array}$ & N (\%) & N (\%) \\
\hline 1 & By contaminated blood and blood products & $190(100)$ & - \\
\hline 2 & Through unsafe sex & $179(94.2)$ & $11(5.8)$ \\
\hline 3 & From mother to child & $172(90.5)$ & $18(9.5)$ \\
\hline 4 & Through the air & $6(3.2)$ & $184(96.8)$ \\
\hline 5 & By eating food with an infections person & $45(23.7)$ & $145(76.3)$ \\
\hline 6 & By holding hands of infected person & $76(40)$ & $114(60)$ \\
\hline 7 & By Sharing towels or Faeco-oral route & $80(42.1)$ & $110(57.9)$ \\
\hline 8 & By sharing toothbrush with an infected person & $159(83.7)$ & $31(16.3)$ \\
\hline 9 & $\begin{array}{l}\text { Unsterilized syringes, needles /surgical instruments } \\
\text { transmit HBV }\end{array}$ & $167(87.9)$ & $23(12.1)$ \\
\hline 10 & Do people get HBV from genes (heredity)? & $17(8.9)$ & $173(91.1)$ \\
\hline 11 & $\begin{array}{l}\text { HBV is more easily spread from person to person than } \\
\text { AIDS }\end{array}$ & $185(97.4)$ & $5(2.6)$ \\
& & &
\end{tabular}

Knowledge about sign and symptoms of HBV infection

12 Do you know the sign and symptoms of HBV infection

$190(100)$

Knowledge about sequela and prevention of HBV infection

\begin{tabular}{lllc}
13 & Could we prevent HB transmission? & $186(97.9)$ & $4(2.1)$ \\
\hline 14 & Is HBV infection treatable? & $144(75.8)$ & $46(24.2)$ \\
\hline 15 & Do you think that HBV has post exposure prophylaxis? & $139(73.2)$ & $51(26.8)$ \\
\hline 16 & Is there an available vaccine for hepatitis B? & $169(88.9)$ & $21(11.1)$ \\
\hline 17 & Do you think HBV can cause liver cancer? & $167(87.9)$ & $23(12.1)$ \\
\hline 18 & Do you think that HBV can affect other organ other than & $111(58.4)$ & $79(41.6)$
\end{tabular}
liver?

The most important source of information for HBV were

\begin{tabular}{llc}
\hline A. & Class room lecture & $129(67.9 \%)$ \\
\hline B. & TV & $8(4.2 \%)$ \\
\hline C. & Radio & $5(2.6 \%)$ \\
\hline D. & Training or Seminar & $26(13.7 \%)$ \\
\hline E. & Others & $22(11.6 \%)$
\end{tabular}




\section{Assessment of practices towards}

\section{Hepatitis B prevention}

Out of the 190 participants, the majority of the respondents $(164,86.3 \%)$, were never screened for HBV and not vaccinated against HBV; only $26(13.7 \%)$ were screened and took three dose of vaccine against HBV. They mentioned different reasons for not being vaccinated: the most common reason (94, 49.5\%) was that the vaccines were costly, lack of availability accounted for $43(22.6 \%)$, not needing it by being very careful $(22,11.6 \%)$, and other reasons such as being too busy and negligence $(5,2.6 \%)$.

Regarding participation in health education programs related to HBV, only $61(32.1 \%)$ of the respondents had participated in health education programs. Concerning standard precautions, 111 (58.4\%) of the respondents of this study were not using standard precautions.

Table IV. Responses of the study participants to Attitudes related to HBV prevention

Attitude items related to HBV prevention

\begin{tabular}{llcc}
\hline & Yes & No \\
\hline 1 & Your job puts you at risk of hepatitis B infection & $\mathbf{N}(\%)$ & $\mathbf{N ~ ( \% ) ~}$ \\
\hline 2 & Do all healthy people need vaccination & $181(95.3)$ & $9(4.7)$ \\
\hline 3 & Hepatitis B vaccine required for complete protection & $149(78.4)$ & $41(21.6)$ \\
\hline 4 & $\begin{array}{l}\text { All patients should be tested for HBV before they receive } \\
\text { health care }\end{array}$ & $125(65.8)$ & $65(34.2)$ \\
\hline 5 & $\begin{array}{l}\text { Do you give the same standard of care to patients with HBV as do } \\
\text { for others }\end{array}$ & $109(57.4)$ & $81(42.6)$ \\
\hline 6 & Education is effective in improving knowledge on hepatitis B? & $183(96.3)$ & $7(3.7)$ \\
\hline 7 & $\begin{array}{l}\text { Standard precautions important to control hospital acquired } \\
\text { infections }\end{array}$ & 190 (100) & -- \\
\hline
\end{tabular}

Table V. Responses of the study participants to practices related to HBV prevention

\begin{tabular}{llccc} 
& Hepatitis B Practice related Items & Yes & No & Practice Score \\
\hline & & N (\%) & N (\%) & Mean \pm SD \\
\hline 1 & Have you been screened for Hepatitis B? & $26(13.7)$ & $164(86.3)$ & $0.14 \pm 0.34$ \\
\hline 2 & Do you use Standard Precautions? & $79(41.6)$ & $111(58.4)$ & $0.14 \pm 0.34$ \\
\hline $\begin{array}{l}\text { Have you ever participated in health } \\
\text { education program related to HBV? }\end{array}$ & $61(32.1)$ & $129(67.9)$ & $0.32 \pm 0.46$ \\
\hline & $\begin{array}{l}\text { Have you been vaccinated against } \\
\text { Hepatitis }\end{array}$ & $26(13.7)$ & $164(86.3)$ & $0.42 \pm 0.49$ \\
If not vaccinated, reason for not being vaccinated & & \\
\hline A. & Cost of vaccination (Not affordable) & $94(49.5 \%)$ & & \\
\hline B. & Vaccine not available & $43(22.6 \%)$ & & \\
\hline C. & Very careful & $22(11.6 \%)$ & \\
\hline D. & Other specify: busy, negligence & $5(2.6 \%)$ &
\end{tabular}


The mean score for HBV prevention related practices was $1.03 \pm 1.07$, revealing poor practices among the study participants (Table V).

\section{Bivariate Analysis}

On bivariate analysis among the demographic variables study department, year of study and marital status of the respondents were significantly associated with mean knowledge (Table VI). Medical students have nearly 24 times more knowledge as compared to anesthesia (crude odds ratio, $\mathrm{COR}=24.381 ; 95 \%$ $\mathrm{Cl}[7.717,77.029])$. Concerning the year of study, the second year students have poorer knowledge than the sixth year students (COR $=0.041 ; 95 \% \mathrm{Cl}[0.009$, 0.187]). Similarly, third and fourth years students have poorer knowledge than the sixth year students $(\mathrm{COR}=$ $0.101 ; 95 \% \mathrm{Cl}[0.027,0.380])$ and $(\mathrm{COR}=0.085 ; 95 \%$ $\mathrm{Cl}[0.023,0.321])$. Respondents who were single had poorer knowledge than married ones $(\mathrm{COR}=0.266$; $95 \% \mathrm{Cl}[0.092,0.722])$.

Table VI. Bivariate analysis for knowledge among medical and health sciences students of College of Medicine and Health Sciences, Dire Dawa University

\begin{tabular}{|c|c|c|c|c|c|c|}
\hline \multirow{2}{*}{\multicolumn{2}{|c|}{ No }} & \multirow[t]{2}{*}{ Variable } & \multicolumn{2}{|c|}{ Knowledge } & \multirow[t]{2}{*}{ COR } & \multirow[t]{2}{*}{ P-value } \\
\hline & & & Poor N (\%) & Good N (\%) & & \\
\hline \multirow{2}{*}{1} & \multirow{2}{*}{ Sex } & Male & $73(70.9 \%)$ & $72(82.8 \%)$ & $1.973[.979,3.973]$ & 0.057 \\
\hline & & Female & $30(29.1 \%)$ & $15(17.2 \%)$ & 1 & 1 \\
\hline \multirow{5}{*}{2} & \multirow{5}{*}{ Age } & $15-19$ & $1(1.0 \%)($ & 0 & $0.000[0.000]$, & 0.999 \\
\hline & & $20-24$ & $84(81.6 \%)$ & $23(26.4 \%)$ & $0.000[0.000]$, & 0.999 \\
\hline & & $25-29$ & $13(12.6 \%)$ & $36(41.4 \%)$ & $0.000[0.000]$, & 0.999 \\
\hline & & $30-34$ & $5(4.9 \%)$ & $23(26.4 \%)$ & $0.000[0.000]$, & 0.999 \\
\hline & & $>=35$ & $0(0 \%)$ & $5(5.7 \%)$ & 1 & 1 \\
\hline \multirow{3}{*}{3} & \multirow{3}{*}{ Department } & Medicine & $21(20.4 \%)$ & $64(73.6 \%)$ & $\begin{array}{c}24.381[7.717 \\
77.029]\end{array}$ & 0.000 \\
\hline & & Midwifery & $50(48.5 \%)$ & $19(21.8 \%)$ & $3.040[.947,9.755]$ & 0.062 \\
\hline & & Anaesthesia & $32(31.1 \%)$ & $4(4.6 \%)$ & 1 & 1. \\
\hline \multirow{5}{*}{4} & \multirow{5}{*}{$\begin{array}{l}\text { Year of } \\
\text { Study }\end{array}$} & $2^{\text {nd }}$ & $23(22.3 \%)$ & $6(6.9 \%)$ & $\begin{array}{c}0.041[0.009,0 \\
.187]\end{array}$ & 0.000 \\
\hline & & $3^{\text {rd }}$ & $36(35.0 \%)$ & $23(26.4 \%)$ & $\begin{array}{c}0.101[0.027,0 \\
.380]\end{array}$ & 0.001 \\
\hline & & $4^{\text {th }}$ & $39(37.9 \%)$ & $21(24.1 \%)$ & $\begin{array}{c}0.085[0.023 \\
0.321]\end{array}$ & 0.000 \\
\hline & & $5^{\text {th }}$ & $2(1.9 \%)$ & $18(20.7 \%)$ & $\begin{array}{c}1.421[0.212 . \\
9.518]\end{array}$ & 0.717 \\
\hline & & $6^{\text {th }}$ & $3(2.9 \%)$ & $19(21.8 \%)$ & 1 & 1 \\
\hline \multirow[t]{2}{*}{5} & \multirow{2}{*}{$\begin{array}{l}\text { Marital } \\
\text { Status }\end{array}$} & Single & $98(95.1 \%)$ & $73(83.9 \%)$ & $\begin{array}{c}0.266[0.092 \\
0.772]\end{array}$ & 0.015 \\
\hline & & Married & $5(4.9 \%)$ & $14(16.1 \%)$ & 1 & 1 \\
\hline \multirow{2}{*}{\multicolumn{2}{|c|}{7 Residence }} & Urban & $64(62.1 \%)$ & $60(69.0 \%)$ & $\begin{array}{c}1.354[0.740 \\
2.477]\end{array}$ & 0.325 \\
\hline & & Rural & $39(37.9 \%)$ & $27(31.0 \%)$ & 1 & 1 \\
\hline
\end{tabular}


Table VII. Bivariate analysis for attitude among medical and health sciences students of College of Medicine and Health Sciences, Dire Dawa University

\begin{tabular}{|c|c|c|c|c|c|c|}
\hline \multirow[t]{2}{*}{ No } & \multicolumn{2}{|c|}{ Variable } & \multicolumn{2}{|c|}{ Attitude } & \multirow[t]{2}{*}{ COR } & \multirow[t]{2}{*}{ P-value } \\
\hline & & & $\operatorname{Bad} N(\%)$ & Good N (\%) & & \\
\hline \multirow[t]{2}{*}{1} & \multirow[t]{2}{*}{ Sex } & Male & $35(70.0 \%)$ & $110(78.6 \%)$ & $\begin{array}{c}1.571[0.759 \\
3.252]\end{array}$ & 0.223 \\
\hline & & Female & $15(30.0 \%)$ & $30(21.4 \%)$ & 1 & 1 \\
\hline \multirow{5}{*}{2} & \multirow{5}{*}{ Age } & $15-19$ & $1(2.0 \%)$ & 0 & 0.000 & 1.000 \\
\hline & & $20-24$ & $25(50.0 \%)$ & $82(58.6 \%)$ & $\begin{array}{c}2.187[0.346 \\
13.829]\end{array}$ & 0.571 \\
\hline & & $25-29$ & $10(20.0 \%)$ & $39(27.9 \%)$ & $\begin{array}{c}2.600[0.381 \\
17.723]\end{array}$ & 0.329 \\
\hline & & $30-34$ & $12(24.0 \%)$ & $16(11.4 \%)$ & $\begin{array}{c}0.889[0.128 \\
6.182]\end{array}$ & 0.905 \\
\hline & & $>=35$ & $2(4.0 \%)$ & $3(2.1 \%)$ & 1 & \\
\hline \multirow{3}{*}{3} & \multirow{3}{*}{ Department } & Medicine & $25(50.0 \%)$ & $60(42.9 \%)$ & $\begin{array}{c}0.300[0.096,0 \\
.937]\end{array}$ & 0.038 \\
\hline & & Midwifery & $21(42.0 \%)$ & $48(34.3 \%)$ & $\begin{array}{c}0.286[0.090 \\
0.911]\end{array}$ & 0.034 \\
\hline & & Anaesthesia & $4(8.0 \%)$ & $32(22.9 \%)$ & 1 & 1 \\
\hline \multirow{5}{*}{4} & \multirow{5}{*}{$\begin{array}{l}\text { Year of } \\
\text { Study }\end{array}$} & $2 \mathrm{nd}$ & $10(20.0 \%)$ & $19(13.6 \%)$ & $\begin{array}{c}1.900[.612 \\
5.902]\end{array}$ & 0.267 \\
\hline & & $3 \mathrm{rd}$ & $12(24.0 \%)$ & $47(33.6 \%)$ & $\begin{array}{c}3.917[1.372 \\
11.181]\end{array}$ & 0.011 \\
\hline & & 4 th & $10(20.0 \%)$ & $50(35.7 \%)$ & $\begin{array}{c}5.000[1.703 \\
14.676]\end{array}$ & 0.003 \\
\hline & & 5 th & $7(14.0 \%)$ & $13(9.3 \%)$ & $\begin{array}{c}1.857[0.536 \\
6.431]\end{array}$ & 0.329 \\
\hline & & 6th & $1(22.0 \%)$ & $1(7.9 \%)$ & 1 & 1 \\
\hline \multirow[t]{2}{*}{5} & \multirow{2}{*}{$\begin{array}{l}\text { Marital } \\
\text { Status }\end{array}$} & Single & $45(90.0 \%)$ & $126(90.0 \%)$ & $\begin{array}{c}1.000[0.341 \\
2.934]\end{array}$ & 1.000 \\
\hline & & Married & $5(10 \%)$ & $14(10 \%)$ & 1 & 1 \\
\hline \multirow[t]{2}{*}{7} & \multirow[t]{2}{*}{ Residence } & Urban & $29(58 \%)$ & $95(67.9 \%)$ & $\begin{array}{c}1.529 \\
{[0.787,2.970]}\end{array}$ & 0.210 \\
\hline & & Rural & $21(42 \%)$ & $45(32.1 \%)$ & 1 & 1 \\
\hline
\end{tabular}

Study department and year of study of the respondents were significantly associated with mean attitude (Table VII). Respondents of Medicine and Midwifery Departments had a more unfavourable attitude than the respondents from the Anaesthesia Department $(\mathrm{COR}=0.300 ; 95 \% \mathrm{Cl}[0.096,0.937])$ and $(\mathrm{COR}=$ $0.286 ; 95 \% \mathrm{Cl}[0.090,0.911])$ respectively. However, fourth and third year students have five and four times better attitude than sixth year students $(C O R=5.000$; $95 \% \mathrm{Cl}[1.703,14.676])$ and $(\mathrm{COR}=3.917 ; 95 \% \mathrm{Cl}$ $[1.917,11.181]$, respectively.

Concerning practices, only the department of the respondents was significantly associated with mean practices (Table VIII). Respondents from Medicine and Midwifery Departments have four and three 
Table VIII. Bivariate analysis for practice among medical and health sciences students of College of Medicine and Health Sciences, Dire Dawa University

\begin{tabular}{|c|c|c|c|c|c|c|}
\hline \multirow[t]{2}{*}{ No } & \multirow[t]{2}{*}{ Variable } & & \multicolumn{2}{|c|}{ Practice } & \multirow[t]{2}{*}{ COR } & \multirow[t]{2}{*}{ P-value } \\
\hline & & & Poor N (\%) & Good N (\% ) & & \\
\hline \multirow[t]{2}{*}{1} & \multirow[t]{2}{*}{ Sex } & Male & $102(75.6 \%)$ & $43(78.2 \%)$ & $\begin{array}{c}1.159[.547 \\
2.456]\end{array}$ & 0.700 \\
\hline & & Female & $33(24.4 \%)$ & $12(21.8 \%)$ & 1 & 1 \\
\hline \multirow{5}{*}{2} & \multirow{5}{*}{ Age } & $15-19$ & $1(0.7 \%)$ & & 0.000 & 1.000 \\
\hline & & $20-24$ & $8(59.3 \%)$ & $27(49.1 \%)$ & $\begin{array}{c}0.225[0.036 \\
1.419]\end{array}$ & 0.112 \\
\hline & & $25-29$ & $36(26.7 \%$ & $13(23.6 \%)$ & $\begin{array}{c}0.241[0.036 \\
1.607]\end{array}$ & 0.141 \\
\hline & & $30-34$ & $16(11.9 \%)$ & $12(21.8 \%)$ & $\begin{array}{c}0.500[0.072 \\
3.477]\end{array}$ & 0.484 \\
\hline & & $>=35$ & $2(1.5 \%)$ & $3(5.5 \%)$ & 1 & 1 \\
\hline \multirow{3}{*}{3} & \multirow{3}{*}{ Department } & Medicine & $55(40.7 \%)$ & $30(54.5 \%)$ & $\begin{array}{c}4.364[1.409 \\
13.517]\end{array}$ & 0.011 \\
\hline & & Midwifery & $48(35.6 \%)$ & $21(38.2 \%)$ & $\begin{array}{c}3.500[1.098 \\
11.154]\end{array}$ & 0.034 \\
\hline & & Anaesthesia & $32(23.7 \%)$ & $4(7.3 \%)$ & 1 & 1 \\
\hline \multirow{5}{*}{4} & \multirow{5}{*}{$\begin{array}{l}\text { Year of } \\
\text { Study }\end{array}$} & $2^{\text {nd }}$ & $25(18.5 \%)$ & $4(7.3 \%)$ & $\begin{array}{c}0.280[0.071 \\
1.099]\end{array}$ & 0.068 \\
\hline & & $3^{\text {rd }}$ & $42(31.1 \%)$ & $17(30.9 \%)$ & $\begin{array}{c}0.708[0.252 \\
1.995]\end{array}$ & 0.514 \\
\hline & & $4^{\text {th }}$ & $46(34.1 \%)$ & $14(25.5 \% 0$ & $\begin{array}{c}0.533[0.185 \\
1.529]\end{array}$ & 0.242 \\
\hline & & $5^{\text {th }}$ & $8(5.9 \%)$ & $12(21.8 \%)$ & $\begin{array}{c}2.625[0.754 \\
9.134]\end{array}$ & 0.129 \\
\hline & & $6^{\text {th }}$ & $14(10.4 \%)$ & $8(14.5 \%)$ & 1 & 1 \\
\hline \multirow[t]{2}{*}{5} & \multirow{2}{*}{$\begin{array}{l}\text { Marital } \\
\text { Status }\end{array}$} & Single & $122(90.4 \%)$ & 49(89.1\%) & $\begin{array}{c}1.149[0.413 \\
3.195]\end{array}$ & 0.790 \\
\hline & & Married & $13(9.6 \%)$ & $6(10.9 \%)$ & 1 & 1 \\
\hline \multirow[t]{2}{*}{7} & \multirow[t]{2}{*}{ Residence } & Urban & $88(65.2 \%)$ & $36(65.5 \%)$ & $\begin{array}{c}1.012[0.524 \\
1.956]\end{array}$ & 0.972 \\
\hline & & Rural & $47(34.8 \%)$ & $19(34.5 \%)$ & 1 & 1 \\
\hline
\end{tabular}

times more likely in practicing standard precautions while caring for their patients than respondents from Anaesthesia Department, respectively $(\mathrm{COR}=4.364$; $95 \% \mathrm{Cl}[1.409,13.517](\mathrm{COR}=3.500 ; 95 \% \mathrm{Cl}[1.098$, 11.154].

\section{Multivariate Analysis}

Based on findings from the bivariate analysis, variables were included in multiple logistic regression models. In multiple logistic regression analysis, it was identified that only department and year of study were associated with knowledge of the respondents (Table IX). Medicine Department respondents were nearly 
Table IX. Multivariate analysis for knowledge among medical and health sciences students of College of Medicine and Health Sciences, Dire Dawa University

\begin{tabular}{|c|c|c|c|c|c|c|}
\hline & \multicolumn{2}{|c|}{ Variable } & \multicolumn{2}{|c|}{ Knowledge } & \multirow[t]{2}{*}{ AOR } & \multirow[t]{2}{*}{ P-value } \\
\hline & & & Poor N (\% ) & Good N (\% ) & & \\
\hline \multirow{3}{*}{1} & \multirow{3}{*}{ Department } & Medicine & $21(20.4 \%)$ & $64(73.6 \%)$ & $12.920[3.602,46.344]$ & 0.000 \\
\hline & & Midwifery & $50(48.5 \%)$ & $19(21.8 \%)$ & $2.973[0.923,9.583]$ & 0.068 \\
\hline & & Anaesthesia & $32(31.1 \%)$ & $4(4.6 \%)$ & 1 & 1 \\
\hline \multirow{5}{*}{2} & \multirow{5}{*}{ Year of Study } & $2^{\text {nd }}$ & $23(22.3 \%)$ & $6(6.9 \%)$ & $0.237[0.041,1.356]$ & 0.106 \\
\hline & & $3^{\text {rd }}$ & $36(35.0 \%)$ & $23(26.4 \%)$ & $0.317[0.074,1.353]$ & 0.121 \\
\hline & & $4^{\text {th }}$ & $39(37.9 \%)$ & $21(24.1 \%)$ & $0.227[0.054,0.954]$ & 0.043 \\
\hline & & $5^{\text {th }}$ & $2(1.9 \%)$ & $18(20.7 \%)$ & $1.403[0.208,9.442]$ & 0.728 \\
\hline & & $6^{\text {th }}$ & $3(2.9 \%)$ & $19(21.8 \%)$ & 1 & 1 \\
\hline \multirow{2}{*}{3} & \multirow{2}{*}{ Marital Status } & Single & $98(95.1 \%)$ & $73(83.9 \%)$ & $0.889[0.250,3.165]$ & 0.856 \\
\hline & & Married & $5(4.9 \%)$ & $14(16.1 \%)$ & 1 & 1 \\
\hline
\end{tabular}

13 times more likely to have good knowledge than respondents from Anaesthesia Department (adjusted odds ratio, $\mathrm{AOR}=12.920 ; 95 \% \mathrm{Cl}[3.602,46.344])$. Similarly, fourth year students have lower knowledge than sixth year students $(A O R=0.227 ; 95 \% \mathrm{Cl}[0.54$, $0.954])$.

With respect to attitude, only department and year of study were associated with good attitude on multivariable analysis (Table X). Respondents from Midwifery Department have poorer attitude than those from Anaesthesia Department $(\mathrm{AOR}=0.291 ; 95 \% \mathrm{Cl}$ $[0.090,0.939])$. Third and fourth years students have four and five times better attitude than sixth year students (AOR $=4.737 ; 95 \% \mathrm{Cl}[1.331,16.848])$ and $(A O R=5.507 ; 95 \% \mathrm{Cl}[1.585,19.127])$.

\section{Discussion}

The current study aimed to assess the knowledge, attitude and practice towards HBV among medical and health sciences students who had taken infectious or communicable diseases course and have started clinical attachment at Dire Dawa University.

In our study, all of the respondents, 190 (100\%), had good knowledge about route of transmission, signs and symptoms, sequelae, treatment, and means of prevention of HBV infection. The result obtained from this study revealed that the study participants had higher knowledge than their corresponding participants involved in similar study conducted at Haramaya University which showed that only 181 (56.2\%) of them had good knowledge. ${ }^{16}$ The present study also showed higher level of participants' knowledge than the result obtained from the study conducted in Iraq, which showed that only $14 \%$ of the participants had good knowledge. ${ }^{17}$ A report from Egypt also showed that only negligible (1\%) number of the participants had good knowledge about HBV. ${ }^{18}$ Even though similar criteria were used to select the participants (those students starting clinical attachment) and the same study type was used as our study, the source population and status of previous experience might resulted in the difference in terms of knowledge. In Haramaya University, study participants were selected from six different departments (Medicine, Public Health Officer, Nurse, Midwifery, Psychiatry and Medical Laboratory) reflecting interdepartmental varieties in acquiring knowledge. Results from a similar study in Iraq in which study participants were selected from both preclinical (first, second and third year) and clinical (fourth, fifth and sixth year) study years of medical students probably revealing lesser experience of preclinical students in acquiring knowledge of HBV compared to well experienced medical students in Dire Dawa University who had exposure to working areas. In Egypt, the study participants were selected from rural and urban high schools who lack basic knowledge about HBV when compared to medical 
Table X. Multivariate analysis for attitude among medical and health sciences students of College of Medicine and Health Sciences, Dire Dawa University

\begin{tabular}{|c|c|c|c|c|c|c|}
\hline & \multicolumn{2}{|c|}{ Variable } & \multicolumn{2}{|c|}{ Attitude } & \multirow[t]{2}{*}{ AOR } & \multirow[t]{2}{*}{ P-value } \\
\hline & & & Poor N (\% ) & Good N (\%) & & \\
\hline \multirow[t]{3}{*}{1} & Department & Medicine & $25(50.0 \%)$ & $60(42.9 \%)$ & $0.507[0.129,2.002]$ & 0.333 \\
\hline & & Midwifery & $21(42.0 \%)$ & $48(34.3 \%)$ & $0.291[0.090,0.939]$ & 0.039 \\
\hline & & Anaesthesia & $4(8.0 \%)$ & $32(22.9 \%)$ & 1 & \\
\hline \multirow[t]{5}{*}{2} & Year of & $2^{\text {nd }}$ & $10(20.0 \%)$ & $19(13.6 \%)$ & $2.393[0.522,10.970]$ & 0.261 \\
\hline & Study & $3^{\text {rd }}$ & $12(24.0 \%)$ & $47(33.6 \%)$ & $\begin{array}{c}4.737[1.332 \\
16.848]\end{array}$ & 0.016 \\
\hline & & $4^{\text {th }}$ & $10(20.0 \%)$ & $50(35.7 \%)$ & $\begin{array}{c}5.507[1.585 \\
19.127]\end{array}$ & 0.007 \\
\hline & & $5^{\text {th }}$ & $7(14.0 \%)$ & $13(9.3 \%)$ & $1.857[0.536,6.431]$ & 0.329 \\
\hline & & $6^{\text {th }}$ & $11(22.0 \%)$ & $11(7.9 \%)$ & 1 & \\
\hline
\end{tabular}

and health students. On the other hand, the result of this study is in line with a study conducted in India which reported a high proportion of medical students $(86.7 \%)$ having good knowledge about HBV. ${ }^{13}$ This might be due to the fact that participants in India were selected only from medical students which parallels the knowledge of medical students in this study.

Regarding routes of transmission, the result from this study showed that participants' knowledge ranges from $76.3 \%$ to $100 \% ; 76.3 \%$ (for absence of transmission by sharing foods with infected individuals), $91.1 \%$ (awareness about non inheritability of HBV from the family) and 100\% (awareness of transmission through contaminated blood and blood products). This is higher than the knowledge status obtained from the study conducted among Vietnamese university students that showed only $55.4 \%$ of the respondents knew the route of HBV transmission and $52.8 \%$ of them misunderstood that HBV can be heritable. ${ }^{19}$ This might be due to the fact that participants in Vietnamese university study had been selected from first year nursing and medical technician students who had not started clinical attachment and lack previous occupational exposure. In contrast, in our study, majority of the participants were particularly medical students who come from different health background with long exposure in working areas and have a higher educational level, and study participants were selected only from those who had started clinical attachments and this might contribute for the greater level of knowledge.

Concerning knowledge assessment on the availability of vaccine against HBV, 169 (88.9\%) of the study participants had information about its existence. This is higher than the proportion of knowledgeable participants obtained from similar studies conducted in Egypt, Ghana and Côte-d'Ivoire which were 42\%, $59 \%$ and $35.7 \%$, respectively. ${ }^{20}, 21$ This might be due to the fact that medical students participated in our study have different health backgrounds and being employed and had exposure in professional jobs.

In our study, 140 participants $(73.7 \%)$ had good attitudes towards HBV where the remaining 50 (26.3\%) had poor attitudes. This showed that participants with poor attitude is higher in our study when compared to the result from the study conducted in Egypt which showed only $14 \%$ of the participants had poor attitudes. $^{18}$

Regarding hepatitis B vaccine requirement, the majority $(78.4 \%)$ of our respondents believe that HBV vaccine is required for healthy individual protection. This is lower than the result from similar study conducted among Vietnamese university students which showed $97.9 \%$ of students believed healthy people need vaccination against HBV. ${ }^{19}$ Regarding 
the attitudes towards standard precautions, all the 190 $(100 \%)$ of the respondents believed that it is the most important means to reduce the risk of transmission of infections. This is similar with the study conducted in Addis Ababa University that showed $94.9 \%$ of the respondents strongly agreed or agreed that standard precautions are important in controlling hospital acquired infections. ${ }^{22}$

Coming to important practices to reduce the spread of HBV from another individual to self and from one person to another, the overall result of this study showed poor practice. In the present study, only 26 (13.7\%) were screened for hepatitis B and took three dose of vaccine against HBV whereas the majority $(164,86.3 \%)$ of the respondents were never screened for hepatitis B and had not been vaccinated against HBV. This finding is consistent with a study conducted in Haramaya University that showed $85.7 \%$ of them were never screened for hepatitis B and only $13.4 \%$ of participants were vaccinated against HBV. ${ }^{16}$ On the other hand, the vaccination coverage against HBV of respondents reported in our study was lower than the result reported in a similar study from Addis Ababa University (22.7\%), ${ }^{22}$ India (63\%), ${ }^{13}$ Pakistan $(62 \%)^{23}$ and Iraq (45\%)..$^{17}$ The difference might be due to socioeconomic differences as can be seen from the major reason for not receiving vaccine is being costly.

Concerning practice towards standard precautions, despite all $190(100 \%)$ respondents having good knowledge and good attitude, only $79(41.6 \%)$ of the respondents used personal protective devices while caring for their patients. However, this is better than a result obtained from study conducted in Addis Ababa University that showed only $6.9 \%$ of respondents have good practicing of standard precautions. ${ }^{22}$ This might be due to previous experience obtained from occupation by our study participants.

\section{Conclusion and Recommendations}

In conclusion, the results from the present study revealed that the study participants among the medical and health sciences students in Dire Dawa University had good knowledge and attitudes towards the hazards, mode of transmission and means of prevention of HBV in general. However, it was observed that their practices were poor towards the prevention of HBV infections.
Based on the results of this study, it is recommended that healthcare professionals must utilize personal protective devices consistently to protect themselves and the nation at large from HBV infections. Furthermore, the Ethiopian government in general and Ethiopian Ministry of Health in particular should ensure availability of vaccine against HBV for medical and health sciences students to suppress the spread of the virus.

\section{Acknowledgements}

The authors of this study would like to thank the respondents for their time and willingness to supply valuable information. Our acknowledgement extends to Dire Dawa University College of Medicine and Health Sciences for facilitating the conditions to conduct this study.

\section{Ethics Approval and Consent to Participate}

The study was approved by Dire Dawa University College of Medicine and Health Sciences Ethical Committee Board. Written informed consent was obtained from all study participants.

\section{Reference}

1. Abate B, Aravind P, Mahafroz K. Healthcare cost and access to care for viral hepatitis in Ethiopia. International Scientific Research Journal 2014; 4(9): 1718-1723.

2. Lavanchy D: Hepatitis B virus epidemiology, disease burden, treatment, and current and emerging prevention and control measures. J Virol Hepat 2004; 11: 97-101. https://doi. org/10.1046/j.1365-2893.2003.00487.x

3. World Health Organization. Prevention \& Control of Viral Hepatitis Infection: Framework for global action. Available Online: http://www.who.int/csr/disease/ hepatitis/ GHP_framework.pdf (Accessed August 21, 2014).

4. Kasper L, Braunwald E. Harrison's principles of Internal medicine. Acute hepatitis. 18 ${ }^{\text {th }}$ Ed. 2012; 1822-1842.

5. WHO. World Health Report 2002; reducing risks, promoting healthy life. Available from: http:/ /www.who.int/whr.

6. Geberemicheal A, Gelaw A, Moges F, Dagnaw M. Seroprevalence of hepatitis B virus infections among health care workers at the Bulle Hora Woreda Governmental Health Institutions, Southern Oromia, Ethiopia. Journal of Environmental and Occupational Science 2013; 2(1): 9-14. https://doi.org/10.5455/jeos.20130220105759

7. Zeleke Y, Gebeyaw T, Tadese E. Occupational exposures to blood and body fluids (BBFS) among health care workers and medical students in University of Gondar Hospital, Northwest of Ethiopia. Global Journal of Medi Research Microbiology and Pathology 2013; 13(3). Available online https://medicalresearchjournal.org/index.php/GJMR/article/ view/367/285

8. Huruy K, Afework K, Andargachew M, Netsanet W, Teshome F. Seroprevalence and risk factors for HBV infection in the 
healthy blood donors at Jimma University Hospital, Ethiopia. Pharmacologyonline 2008; 3: 32-37.

9. Gelaw B, Mengistu Y. The prevalence of HIV, HCV and Malaria parasites among blood donors in Amahara and Tigray regional states Ethiop / Health Dev 2008; 22: 3-7. https://doi. org/10.4314/ejhd.v22i1.10056

10. Habte Y. A Thesis Submitted to the College of Health Sciences, School of Graduate Studies, Haramaya University in Partial Fulfillment of the Requirements for the Degree of Master of Public Health in General Public Health, May, 2015.

11. Federal Ministry of Health (FMOH). Ethiopia National Expanded Programme on Immunization; comprehensive multi-year plan 2011 - 2015. Addis Ababa Dece, 2010.

12. Ganczak M, Barss P, Alfaresi F, Almazrouei S, Muraddad A, Al-Mskari F. Break the silence: HIV/AIDS knowledge, attitudes, and educational needs among Arab university students in United Arab Emirates. Journal of Adolescent Health 2007; 40(6): 572. https://doi.org/10.1016/j.jadohealth.2007.01.011

13. Singh A, Jain S. Prevention of hepatitis B - Knowledge and practices among medical students. Healthline 2011; 2(2): 8-11.

14. Ethiopian Radio and Television Agency (ERTA). Ethiopia undertaking hepatitis vaccination program. Available Online http://www.ertagov.com/news/index.php/ component/k2/ item/258-ethiopia-undertaking-hepatitis-vaccination-program (Accessed August 21, 2014).

15. Daniel Wayne W. Biostatistics - A Foundation for Analysis in the Health Sciences, $6^{\text {th }}$ edition, 1929. Pg 180.
16. Mesfin YM, Kibret KT. Assessment of knowledge and practice towards Hepatitis B among medical and health science students in Haramaya University, Ethiopia. PLoS ONE 2013; 8(11): e79642. https://doi.org/10.1371/journal.pone.0079642

17. Othman SM, Saleh AM, Shabila NP. Knowledge about HBV infection among Medical students in Erbil City, Iraq. European Scientific Journal 2013; 3: 299-305.

18. Salem MA, Shazaly HA, Salama A, Elseidy AA. Knowledge and attitudes regarding hepatitis viruses among secondary-school students in Menoufia governorate. Menoufia Med / 2015; 28: 415-419. https://doi.org/10.4103/1110-2098.163894

19. Dahlström E, Funegård Viberg E. Knowledge about hepatitis $B$ virus infection and attitudes towards hepatitis B virus vaccination among Vietnamese university students in $\mathrm{Ho}$ Chi Minh City. Thesis in Caring Sciences 2013.

20. Batholomew C. KAP concerning hepatitis B among adolescents in the upper west region of Ghana [dissertation]; Umeå University, Sweden; 2011.

21. Lohouès-Kouacou MJ, Assi C, Ouattara A, et al. Hepatitis B knowledge among $2^{\text {nd }}$ school students in Côted'Ivoire. Sante Publique 2013; 21: 110-113.

22. Tarko Sh, Azazh A, Abebe Y. Assessment of the knowledge, attitude and practice of fourth, fifth and sixth year medical students on standard precaution in Tikur Anbessa Specialized Hospital, Addis Ababa, Ethiopia, 2014. Research \& Reviews: Journal of Nursing and Health Sciences 2015; 1(3): 34-40

23. Jadoon NA, Shahzad MA, Yaqoob R, Raza A, Hussain MI. Hepatitis B Vaccination status of health care workers at a tertiary care hospital in Multan. Nishtar Medical Journal 2009; 1(1): 23-27. 